\title{
Analysis of Technical Forehand Boys Athlete Junior UNNES Tennis Club
}

\author{
Rivan Saghita Pratama ${ }^{1}$, Sri Haryono ${ }^{2}$, Limpad Nurrachmad ${ }^{3}$ \\ \{rivan.saghita.pratama@mail.unnes.ac.id ${ }^{1}$, sriharyono@mail.unnes.ac.id ${ }^{2}$, \\ limpad.edu@mail.unnes.ac.id $\left.{ }^{3}\right\}$ \\ Universitas Negeri Semarang, Semarang, Indonesia ${ }^{1,2,3}$
}

\begin{abstract}
The purpose of this study are to analyze and measuring the forehand technique of boys athletes Unnes Tennis Club (UTC) junior based on the ready position, to analyze and measuring the forehand technique of boys athletes UTC based on racket grip and grip strength, to analyze and measuring the forehand technique of boys athletes UTC based backswing movements, to analyze and measuring the forehand technique of boys athletes UTC based on the racket's impact. Type of this research is a descriptive analysis research with quantitative and qualitative approaches. This research will analyze and present the facts of the problematic symptoms systematically so that is easier to understand and conclude. This research will be carried out at the UNNES Tennis Court, Gunungpati, Semarang City. The sampling technique in this research was purposive sampling. The sample in this research amounted to 14 boys athletes.
\end{abstract}

Keywords: Analysis, forehand, tennis, junior.

\section{Introduction}

Sport are all aspects related $\mathrm{t}$ sports theth require regulation, education, training, coaching, development and supervision [1]. This process of regulating, training, coaching, developing, and supervising can be systemized in an association forum, namely a sports club. The sports aspect carried out by the club aims to create and improve sports achievements. Achievement sports are sports that foster and develop athletes in a planned, tiered and sustainable manner through competitions to achieve achievements with the support of sports science and technology [1].

Unnes Tennis Club (UTC) is a sports club that accommodates tennis observers in the Universitas Negeri Semarang (UNNES) and its surroundings. The main task and function of this club is to assist UNNES in developing potential achievements, potential income through assets, and potential development of patner coorporation. The development of potential achievements carried out by UTC is to form Unnes Tennis Club Junior. UTC Junior consists of 19 children aged 10-16 years old.

In the game of tennis, scoring is the result of a series of strokes taken by the player. The series of strokes is carried out repeatedly so that accumulatively will form game patterns [2]. This pattern of play will be formed if an athlete has good hitting skills. The average training age for UTC junior athletes is 9 months. The mastery of punches is still very poor, so the game pattern cannot be implemented properly. Currently the world is experiencing a crisis on a very large scale that has never happened before in modern times, namely the covid-19 pandemic [3]. 
Corona virus disease 2019 (corona virus disease/covid-19) is a new name that given by the World Health Organization (WHO) for patients with the 2019 corona virus infection which was first reported from the city of Wuhan [4]. The covid-19 pandemic has made governments in various countries enforce strict health protocols, such as regulations that undoubtedly interfere with sporting events and a number of other aspects. In order to maintain the health of athletes and other parties involved in sports activities, most sporting events, both at the national, regional and international levels have been postponed until an undetermined time limit or cancellation. The postponement of a number of sporting events makes the coaches to reschedule the exercise program that has been made so that their body fitness can remain at home [5].

This activity limitation is thought to have an impact on the athletes' movement competence and even to the occurrence of injuries. Based on the results of research published in the journal Medicine \& Science in Sport \& Exercise The Official Journal of the American College of Sports Medicine with the title The Accuute: Chronic Workload Ratio Is Associated with Injury in Junior Tennis Players, the conclusion is that injured players have an average 1.5 times more weight training done in the last week compared to the previous 4 weeks. The majority of the players continued training to cover injuries and were not ready for the training load they were experiencing [6]. Movement competence involves two very fundamental things, namely motor skills and body coordination [7]. Basically, motor development can be divided into two, namely gross motoric and fine motoric. Gross motor skills are a part of motor activity that includes large muscle skills, such as crawling, prone, neck lifting, and sitting. Fine motor skills are part of motor activities that involve the movement of small muscles, such as picking up small objects with the thumb and forefinger, drawing, and writing [8].

Basic Sports Techniques Tennis consists of groundstroke, serve, volley and half volley. The groundstroke is divided into 2, namely the forehand groundstroke and the backhand groundstroke. The forehand has become the weapon of choice for most tennis players today. The style of play will be affected by how well the player takes this shot. The forehand is often the core strategy of both players in competition; a player can develop a game plan. A good forehand has the strength of consistency, accuracy and variety. This allows players to beat opponents in ways ranging from defending to attacking with one shot, or placing opponents in a defensive position to transitioning towards the net. Players with strong forehands include Andy Roddick, Roger Federer, Rafael Nadal, Venus Williams, and Serena Williams [9].

The forehand stroke involves a number of muscles and joints in the body. In addition to the core movements that are often used in the arm area, in carrying out a series of forehand strokes, an athlete also pays attention to footwork when running kicks the ball and maintains his body weight when hitting the ball [10]. In the sport of tennis, athletes must ensure their forehand strokes can anticipate a variety of conditions including variations in the spin speed and bounce of the incoming ball, as well as different target areas and amounts of psychological stress [11].

Motion biomechanics experiments can measure the load on the body and describe the behavior of the equipment used. In tennis, a stiffer tennis racket and a lower gripping force reduce the mechanical load on the arm, without compromising ball speed. A novice tennis player who hits the ball too close to the hand and experiences a much higher vibration in the wrist. Biomechanical measurements can identify significant deficiencies in racket performance predicted by theoretical studies [12].

An athlete and coach must be able to analyze the motion of the strokes made during a training session. Good analytical skills of an athlete aim to carry out movement correction as soon as possible, when the athlete makes a stroke that is not in accordance with the target area. Good analytical skills from a coach are also needed to provide input to athletes and provide 
treatment for movements, so that these movements become effective and efficient. Analysis of motion in this sport uses the basics of sports biomechanics.

Based on the observations of the research team in the field, the coaching team has not yet carried out a detailed analysis of the athlete's forehand stroke movement. The team of trainers only made movement corrections using their visual analysis and delivered corrections verbally without the aid of analytical tools or software. This method of analysis is still conventional and the coaching team does not get measurable training progress.

Based on the above problems, the research team will make a quantitative and qualitative analysis of the forehand strokes of Unnes Tennis Club Junior athletes with the title "Analysis of Technical Forehand Boys Athlete Junior Unnes Tennis Club "2021.

\section{Methods}

\subsection{Type of research}

In accordance with the problems described, this research was carried out using descriptive analysis research with qualitative and quantative approaches. Namely, analyzing and presenting the facts of the symptom that is a systematic problem so that it can be easier to implement and state [13]. The research team describes the implementation of this research into a research design chart as follows:

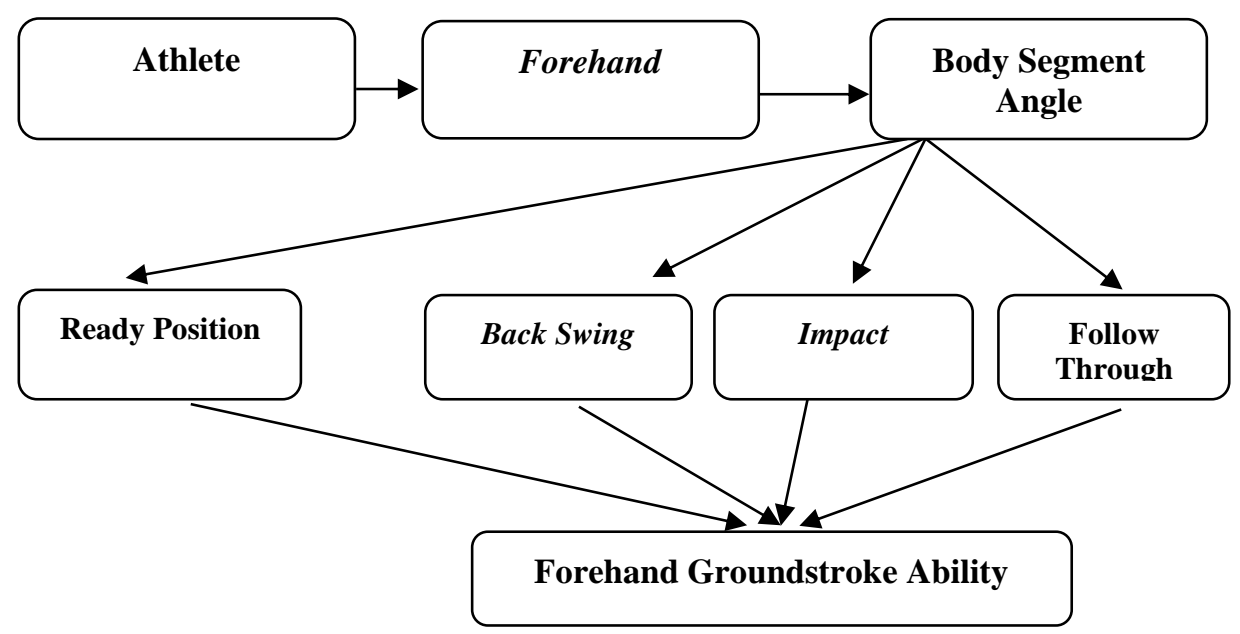

Fig. 1. Chart of tennis groundstroke forehand research design

Based on this chart, it can be explained in this descriptive analysis research, the qualitative approach only reaches the description stage, namely analyzing the records and stages of the forehand grounstroke movement. Meanwhile, the quantitative approach provides measurements and calculations using the Dartfish program related to body segment angles, backswing, racket impact motion with the ball, and systematic follow-up movements so that it is easier to understand and conclude. 


\subsection{Research instruments}

Retrieval of data in research requires appropriate instruments or tools. So that these tools are able to measure what you want to measure. In this study, the Dartfish software program was used. To get the data to be analyzed by the Dartfish program, supporting tools are needed to collect the data. The facilities and infrastructure needed include a tennis court, a handy camera, a digital camera, a tripod, paper, a whistle and writing instruments.

Dartfish is a software that basically someone needs to measure something that can't be seen by the eye's eye. This software is equipped with a camera, this software can analyze movement but the tendency is qualitative, manipulation of movement variables cannot be done directly. Dartfish can be used to slow down a movement and stop motion, measuring length, angle of body segments, speed and acceleration of motion and timing. Simulation can be done but not directly. The results of the recorded images can then be transferred to a computer, so that the recorded video images can be analyzed according to the wishes of the observer. Dartfish is specialized in the production of interactive, entertaining and educational video analytics and digital image processing.

Dartfish are produced by the United States. Dartfish USA, Inc. 1301 High tower trail suite III, Atalanta, Georgia 30350. The program facilities available in this software are:

1. Dv Import: transfer clips from digital cameras or camcorders to a computer.

2. Dv Export: transfer clip from computer to camera.

3. Player: Play clip pictures or videos, slomotion frame by frame or full screen.

4. Analizer: analyzing other movements in terms of body segments, movement trajectories, speed, time and distance, this facility can also compare the appearance of two athletes.

5. Simulcam: comparing two movements with different execution times.

6. Stromotion: shows the stages of the movement from the beginning to the next.

7. Producer: describes and at the same time provides comments, as well as product communication through infonates or other media.

A video of the motion of the forehand groundstroke was observed using two cameras. The first camera to use a tripod with a handy camera note that it is perpendicular to the trajectory of the motion which is also perpendicular to the direction of the trajectory of the motion, but is at the side of the subject. While the second camera is on the back so the direction of the motion trajectory will be recorded from the rear point of view.

\subsection{Data collection methods}

Execution test for groundstroke forehand motion:

The Goal : to find out the forehand groundstroke motion and to obtain information and data from the analysis of the forehand groundstroke movement of UTC Junior boys athletes.

Tools : Dartfish, handy cameras, digital cameras, tripods, writing instruments, racquets, tennis balls, computers and the Dartfish software program.

Stages of the test: The data collection techniques of this research are; The initial step taken is to re-record the subject to be studied. Furthermore, the subject is given an explanation of the procedures or rules in data collection in the hope that the subject will make a serious forehand grounstroke movement. After the subject understands all the procedures or rules in data collection, then it is followed by a forehand groundstroke motion test. The test is carried out one by one in order to determine the forehand groundstroke motion.

After being called by name, the subject stood up and took the position of executing the forehand groundstroke behind the prepared baselane line. Furthermore, the subject performs a 
forehand groundstroke, in which the subject makes the best possible forehand groundstroke and is directed to a predetermined target. In the data collection technique, the execution of the stroke is recorded using 2 handy cameras using a tripod with the note that the handy camera is perpendicular to the direction of the motion trajectory as well as perpendicular to the direction of the motion trajectory, but at the side of the subject.

While the second camera is behind the target of being hit so that the direction of the trajectory of the blow from the rear viewpoint will be recorded. Furthermore, Besier states that the correct placement of the camera and tripod will determine the angles of the body segments which allow them to be analyzed in detail and accurately with the latest advances in computer technology. The number of subjects in this study were recorded as many as 14 athletes. Furthermore, the recording is changed in the form of clip movements (video clip) with the extension avi. The file is then entered into the Dartfish software program.

Expert Judgment : In this Expert Judgment, it is to find out the suitability and correctness of the throwing technique performed by the subject. The Expert Judgment stage is carried out by providing the results of data processing that have been analyzed with the Dartfish software program to: (1) One academic, (2) One person who is an expert in operating the dartfish software, (3) One national licensed tennis coach.

Test Administration Instructions: The subject is in the ready position and a feeder is on the other side of the net. The feeder directs the ball to the right of the athlete. Each subject performs 2 tests with 1 kind of movement, namely forehand groundstroke. Each research subject hit 3 times. The research subjects carried out a punch motion using their dominant hand. The interval between strokes and the other is 25 seconds. This refers to the ITF rules between points.

performance assessment : The motion of the forehand groundstroke is recorded into a digital camera or handy camera then the results of the recording are processed into a program called Dartfish. The overall results of the recorded forehand groundstroke strokes are analyzed for movement errors which include backward racket swing motion, racket ball hitting motion, and follow-up movements. After that Expert Judgment will assess and determine several strokes that match the criteria of the stroke and the result of the stroke in a good and correct position. From the analysis and assessment of Expert Judgment, the data will obtain an assessment for each movement error made by each athlete, as well as the most frequent movement errors made by athletes.

\subsection{Data analysis technique}

Data analysis or processing is an important step in research activities, especially if we want to draw conclusions about the problem under study. In accordance with the descriptive type of analysis, it will discuss the arrangement of data into lists, graphs, pictures, or other forms [13]. The movement of the forehand groundstroke was recorded using 2 camcorders using a tripod with the record that the first camcorder was perpendicular to the direction of the motion trajectory and the target. The first Handycam is perpendicular to the trajectory of the motion, but at the side of the subject. While the second camcorder is behind the target so that the direction of the movement trajectory will be recorded from the rear viewpoint.

In this study, the data analysis technique used the Dartfish software program. The recorded forehand groundstroke is then entered into a laptop or computer. The recording of the forehand groundstroke stroke that is inserted into the laptop has been converted into the form of videoclip movements, then the clip movements are analyzed using the Dartfish software program using the Analizer facility. By using the Analizer facility in the Dartfish video clip software program, it can be analyzed. For a quantitative explanation of movement analysis focused on 
measurements relating to the angles of the body segment, target accuracy, arm angle, torso inclination at the time of hitting position. And a qualitative explanation is about the stages of movement when making a forehand groundstroke stroke, from time to time from the start of kicking to the impact of kicks. These movements are broken down into several stages of movement, each movement is shown the sequence of movements along with the time when the movement takes place.

From this qualitative explanation, it can be described the stages of movement of the forehand groundstroke from the corners of the body segments, how the angles of the arms, the position of the legs when hitting, the head, and other body parts. The 14 tennis athletes were given the opportunity to hit 3 times. The total strokes made by the research subjects amounted to 3 strokes.

The results of the analysis that have been obtained will be used as a profile for each individual. So that each athlete can find out the movement errors made when making a forehand groundstroke, as well as the most frequent mistakes made by UTC junior tennis athletes.

\section{References}

[1] Undang-Undang Nomor 3 Tahun 2005 Tentang Sistem Keolahragaan Nasional. Vol. 1, Regulation. 2005.

[2] Sukadiyanto. Prinsip-prinsip Pola Bermain Tenis Lapangan. J Olahraga Prestasi. 2005;1(4):261-81

[3] Setyaningrum DAW. Pentingnya olahraga selama pandemi COVID-19. J Biomedika dan Kesehat. 2020;3(4):166-8.

[4] Handayani D. Penyakit Virus Corona 2019. J Respirologi Indones. 2020;40(2):129.

[5] Kardiyanto DW. Dampak Pandemi Covid-19 Terhadap Event Olahraga dan Sosial Ekonomi Masyarakat [Internet]. uns-opinion. 2020. Available from: https://uns.ac.id/id/uns-opinion/dampakpandemi-covid-19-terhadap-event-olahraga-dan-sosial-ekonomi-masyarakat.html

[6] Myers NL, Aguilar K V., Mexicano G, Farnsworth JL, Knudson D, Kibler WBEN. The Acute:Chronic Workload Ratio Is Associated with Injury in Junior Tennis Players. Med Sci Sports Exerc. 2020;52(5):1196-200.

[7] Rudd J, Butson ML, Barnett L, Farrow D, Berry J, Borkoles E, et al. A holistic measurement model of movement competency in children. J Sports Sci. 2016;34(5):477-85.

[8] Sujarwo, Widi CP. Kemampuan Motorik Kasar dan Halus Anak Usia 4-6 Tahun. J Pendidik Jasm $\begin{array}{llll}\text { Indones } & \text { [Internet]. } & 2015 ; 11(2): 96-100 . & \text { Available }\end{array}$ https://journal.uny.ac.id/index.php/jpji/article/view/8185/6856

[9] Rive J, Williams S. Tennis skills \& drills [Internet]. 2012. 263 p. Available from: www.HumanKinetics.com

[10] Abdurrhamat AS. Analisis Biomekanik Pukulan Forehand Pada Olahraga Tenis. J Heal Sport [Internet]. 2011;2:161-74. Available from: file:///C:/Users/pc/Downloads/83-76-1-PB.pdf

[11] Reid M, Elliott B, Crespo M. Mechanics and learning practices Associated with the Tennis forehand: A review. J Sport Sci Med. 2013;12(2):225-31.

[12] Hennig EM. Influence of racket properties on injuries and performance in tennis. Exerc Sport Sci Rev. 2007;35(2):62-6.

[13] Maksum A. Metodologi Penelitian dalam Olahraga. Surabaya: Unesa University Perss; 2012. 257 p. 